\title{
PENGARUH PENAMBAHAN UREA DAN SULFUR PADA LIMBAH PADAT BIOETANOL YANG DIFERMENTASI EM-4 TERHADAP KANDUNGAN PROTEIN DAN SERAT KASAR
}

\author{
The Effect of Urea and Sulfur Addition in Solid Waste Bioethanol Fermented by EM-4 on Contents of \\ Crude Protein and Fiber
}

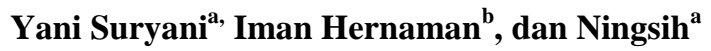 \\ ${ }^{a}$ Department of Biology, Faculty of Science and Technology Universitas Islam Negeri Sunan Gunung \\ Djati Bandung Jl. A.H Nasution No.105 Bandung 40614 \\ ${ }^{\mathrm{b}}$ Departement of Animal Nutrition and Feed Technology, Faculty of Animal Husbandry, \\ Universitas Padjadjaran, Jl. Raya Bandung-Sumedang Km.21 Jatinangor \\ email : iman_hernaman@yahoo.com
}

\begin{abstract}
Cassava processing into bioethanol potentially generates waste as animal feed, but the content of nutrients is still low. This research aims to discover effect of urea and sulfur addition in solid waste bioethanol fermented by EM-4 on contents of crude protein and fiber. The research used the experimental methods with completely randomized design, factorial pattern $3 \times 3$ with 3 time of replicates. The first factor, supplementation of Nitrogen is Urea $(\mathrm{N1}=0 \%, \mathrm{~N} 2=1,5 \%, \mathrm{~N} 3=3 \%)$ and the second factor is supplementation of sulfur $(S 1=0 \%, S 2=0,02 \%, S 3=0,04 \%)$. Based on the results of variance analysis showed that there is an interaction between urea with sulfur on content of protein crude, but not on fiber crude. Addition of each urea and sulfur showed that the content of crude protein was increased $(P<0,05)$ and the level of crude fiber $(P<0,05)$ was decreased. Fermentation along 4 day on treatment of urea $3 \%$ and sulfur 0,04\% produce crude protein and fiber of $14,44 \%$ and $6,97 \%$, respectively. Conclusion, addition of urea $3 \%$ and sulfur $0,04 \%$ give the good results.
\end{abstract}

Keywords: Bioethanol, EM-4 (Efective Microorganisms4), Crude Protein, Crude Fiber, Sulfur and Urea

\section{PENDAHULUAN}

Bioetanol merupakan etanol yang berasal dari bahan nabati. Bioenergi ini diproduksi dengan teknologi fermentasi, dimana salah satu bahan pembuatannya berasal dari singkong. Pembuatan bioetanol dari singkong menghasilkan limbah yang cukup banyak. Dari proses pengolahan singkong menjadi bioetanol, dihasilkan limbah sekitar $2 / 3$ bagian atau sekitar $75 \%$ dari bahan mentahnya (Pratomo dan Rohaeti. 2011).

Limbah industri bioetanol termasuk ke dalam limbah padat organik yang belum termanfaatkan secara maksimal. Limbah padat tersebut dapat digunakan sebagai pakan ternak alternatif. Namun sebelum diaplikasikan pada ternak, sebaiknya limbah tersebut diberikan perlakuan untuk meningkatkan kandungan nutrien pada pakan karena limbah bioetanol mengandung protein yang rendah dengan serat kasar yang tinggi yaitu $2,25 \%$ dan $16,57 \%$ (Yani, et al. 2013).
Salah satu cara yang bisa digunakan untuk meningkatkan kandungan nutrien limbah bioetanol yaitu dengan melakukan proses fermentasi. Fermentasi merupakan suatu proses terjadinya perubahan kimia pada suatu substrat organik melalui aktivitas enzim yang dihasilkan oleh mikroorganisme (Suprihatin, 2010).

Percepatan fermentasi dan pertumbuhan mikroorganisme memerlukan nutrien tambahan. Selain memerlukan karbohidrat, juga membutuhkan nitrogen dan mineral yang cukup untuk dapat tumbuh dan produksi dengan optimal (Akbar, et al. 2013 dan Suryani, et al. 2013).

Fermentasi selain menggunakan kapang atau khamir, juga dapat dilakukan dengan bakteri atau campuran berbagai mikroorganisme. Sebagai salah satu contoh yaitu dapat menggunakan EM-4 (Efective Microorganisms 4). Kultur ini adalah campuran mikroorganisma yang mengandung Lactobacillus, jamur fotosintetik, bakteria fotosintetik, Actinomycetes, dan ragi dan telah 
banyak dibuktikan bahwa EM-4 ini memiliki kemampuan untuk menurunkan kadar serat kasar dan meningkatkan palatabilitas bahan pakan (Kukuh, 2010).

\section{MATERI DAN METODE}

EM-4 yang digunakan dalam penelitian ini diproduksi oleh PT. Songgolangit Persada. Sebelum digunakan terlebih dahulu diaktifkan yaitu, sebanyak $30 \mathrm{~mL}$ dicampurkan dengan 30 gram gula merah dalam Erlenmeyer. Lalu ditambah aquades steril sampai $1000 \mathrm{~mL}$ dan disimpan pada suhu ruang dengan kondisi anaerob selama 24 jam (Islamiyati, 2014) siap digunakan sebagai inokulum.

Limbah padat pengolahan bioethanol disterilkan dengan cara diautoklaf dengan suhu $121^{0} \mathrm{C}$ dan tekanan 1 atm selama 15 menit. Lalu dibiarkan selama 30 menit sampai uap air keluar dan limbah menjadi dingin, setelah itu ditimbang masing-masing sebanyak 250 gram. Sumber nitrogen (urea) dan sumber sulfur (sodium sulfat) ditambahkan sesuai dengan perlakuan. Kemudian EM-4 1\% ditambahkan ke dalam substrat, aduk sampai rata dan masukkan ke dalam plastik yang diberi lubang kecil untuk mendapatkan kondisi aerob dan disimpan pada kondisi suhu kamar $\left(27^{\circ} \mathrm{C}\right)$ selama empat hari. Produk fermentasi dikeringkan dengan menggunakan oven pada suhu $60^{\circ} \mathrm{C}$ selama 24 jam, setelah kering digiling untuk keperluan analisis protein kasar dan serat kasar (AOAC, 1980).

Penelitian ini menggunakan metode eksperimental dengan rancangan acak lengkap (RAL) pola faktorial $3 \times 4$. Faktor pertama adalah taraf suplementasi nitrogen $(\mathrm{N} 1=0 \%$, $\mathrm{N} 2=1,5 \%, \mathrm{~N} 3=3 \%$ ) dan faktor kedua adalah taraf suplementasi sulfur $(\mathrm{S} 1=0 \%, \mathrm{~S} 2=0,02 \%$, $\mathrm{S} 3=0,04 \%$ ). Data yang terkumpul dianalisis dengan analisis varians (ANAVA) pada taraf kepercayaan $95 \%$ untuk mengetahui adanya pengaruh terhadap perlakuan. Jika terdapat pengaruh yang nyata pada perlakuan dilanjutkan dengan Uji Duncan (Steel dan Torrie, 1993).

\section{HASIL DAN PEMBAHSAN}

\section{Pengaruh Penambahan Urea dan Sulfur terhadap Kandungan Protein Limbah Padat Bioetanol Hasil Fermentasi}

Hasil analisis sidik ragam menunjukan terdapat interaksi antara urea dengan sulfur $(\mathrm{P}<$ 0,05) terhadap kandungan protein kasar substrat. Terjadinya interaksi antara urea dan sulfur menunjukan bahwa penambahan urea dan sulfur saling memberikan pengaruh terhadap pertumbuhan mikroorganisme selama proses fermentasi. Demikian pula secara mandiri terdapat perbedaan yang nyata $(\mathrm{P}<0,05)$ untuk masing-masing faktor, yaitu faktor perlakuan urea dan sulfur. Terdapat interaksi antara urea dan sulfur terhadap kandungan protein kasar disebabkan kedua unsur tersebut sangat dibutuhkan bagi perkembangan mikroorganisme. Menurut Manfaati (2010), urea sebagai sumber nitrogen dan sulfur merupakan makronutrien untuk pertumbuhan mikroorganisme. Kedua unsur tersebut akan membentuk komponen protein mikroba, terutama sulfur lebih dibutuhkan dalam pebentukan asam amino esensial yang mengundung sulfur seperti seperti sistin, sistein, dan metionin (Dhalika et al. 2012

Adanya perbedaan yang nyata dari masing-masing faktor perlakuan, dilakukan Uji Duncan. Tabel 2 menyajikan bahwa semakin tinggi penambahan urea semakin besar kandungan protein kasar, dimana kandungan tertinggi diperoleh pada perlakuan N3, yaitu $14,09 \%$.

Tabel 1. Uji Duncan Pengaruh Perlakuan Urea terhadap Kandungan Protein Kasar

\begin{tabular}{ccc}
\hline Perlakuan & $\begin{array}{c}\text { Rataan } \\
\text { Protein } \\
\text { Kasar (\%) }\end{array}$ & $\begin{array}{c}\text { Signifikasi } \\
(\mathbf{0 , 0 5})\end{array}$ \\
\hline N1 & 2,27 & $\mathrm{a}$ \\
N2 & 10,22 & $\mathrm{~b}$ \\
N3 & 14,09 & $\mathrm{c}$ \\
\hline Keterangan : & Superskrip huruf yang berbeda \\
& pada kolom signifikasi & sign \\
& menunjukkan & berbeda nyata \\
& $(\mathrm{P}<0,05)$ &
\end{tabular}

Peningkatan nilai kandungan protein produk fermentasi limbah padat bioetanol disebabkan urea yang ditambahkan akan dikonversi oleh mikroorganisme menjadi protein (Suryani, et al. 2013). Kenaikan kandungan protein limbah bioetanol disebabkan karena pertumbuhan Saccharomyces cerevivisiae, Lactobacillus casei dan Rhodopseudomonas palustris lebih optimal. Pertumbuhan mikroba sangat dipengaruhi oleh ketersediaan sumber energi, sumber $\mathrm{N}$ dan beberapa mineral terutama $\mathrm{S}$ dan P (Suprayogi, 2010).

Urea berfungsi sebagai sumber nitrogen (N) selama proses fermentasi. Penambahan urea mampu meningkatkan kandungan protein secara optimal. Diketahui kandungan nitrogen yang terdapat dalam urea sebanyak $42 \%-45 \%$ atau setara dengan protein kasar antara $262 \%$ - 
$281 \%$ (Permata, 2012). Urea juga berfungsi sebagai substrat bagi mikroorganisme, karena selama proses fermentasi kandungan gizi dalam urea dimanfaatkan oleh mikroorganisme untuk sintesis protein tubuhnya. Sintesis protein adalah proses memproduksi senyawasenyawa polipeptida dalam tubuh sel yang berguna untuk pewarisan sifat secara genetis kepada keturunannya (Irawan dan Utama, 2012). Terjadinya sintesis protein, mengakibatkan mikroorganisme seperti Saccharomyces cerevivisiae, Lactobacillus casei dan Rhodopseudomonas palustris berkembang biak dan akan meningkatkan kandungan protein dalam limbah meningkat meningkat.

Dosis pemberian sulfur (Tabel 2) memberikan pengaruh yang nyata $(\mathrm{P}<0,05)$ terhadap kandungan protein kasar. Penggunaan sulfur dengan dosis $0,04 \%$ (S3) menghasilkan nilai rata-rata tertinggi kandungan protein kasar pada limbah padat bioethanol sebesar $9,14 \%$. Fermentasi dengan penambahan sulfur dapat meningkatkan bahan organik, kandungan protein secara signifikan $(\mathrm{P}<0,05)$. Fungsi dari mineral sulfur dalam fisiologi dari sel mikroba yaitu bagian dari protein asam amino sistein dan metionin dan bagian dari beberapa enzim (CoA, Co-enzym A carboxylase) (Akib, et al. 2014).

Tabel 2. Uji Duncan Pengaruh Perlakuan Sulfur terhadap Kandungan Protein Kasar

\begin{tabular}{ccc}
\hline Perlakuan & $\begin{array}{c}\text { Rataan } \\
\text { Protein } \\
\text { Kasar }(\%)\end{array}$ & $\begin{array}{l}\text { Signifikan } \\
(\mathbf{0 , 0 5})\end{array}$ \\
\hline S2 & 8,67 & $\mathrm{a}$ \\
S1 & 8,76 & $\mathrm{a}$ \\
S3 & 9,14 & $\mathrm{~b}$ \\
\hline
\end{tabular}

Keterangan : Superskrip huruf yang berbeda pada kolom signifikasi menunjukkan berbeda nyata $(\mathrm{P}<0,05)$

\section{Pengaruh Penambahan Urea dan Sulfur terhadap Kandungan Serat Kasar Limbah Padat Bioetanol Hasil Fermentasi}

Serat kasar merupakan salah satu komponen penyusun karbohidrat diantaranya lignin, selulosa dan hemiselulosa. Hasil analisis sidik ragam menunjukan bahwa tidak ada interaksi antara urea dan sulfur $(\mathrm{P}>0,05)$. Artinya bahwa tidak saling mempengaruhi antara faktor urea dengan faktor sulfur. Namun, masing-masing faktor pemberian urea dan sulfur memberikan pengaruh yang nyata $(\mathrm{P}<0,05)$ terhadap kandungan serat kasar.
Hasil Uji Duncan Tabel 3 menunjukan bahwa pemberian urea memberikan pengaruh yang nyata terhadap penurunan kandungan serat kasar $(\mathrm{P}<0,05)$. Hasil rata-rata kandungan serat kasar terendah yaitu terdapat pada perlakuan pemberian urea 3\% yaitu dengan rata-rata kadar serat kasar 7,46\%. Jadi semakin tinggi penambahan dosis urea menunjukan hasil dapat menurunkan kandungan serat kasar pada limbah padat bioethanol setelah dilakukan fermentasi. Urea merupakan sumber nitrogen dan karbon yang merupakan makanan bagi mikroogranisme sehingga fermentasi berjalan dengan baik. Penambahan urea dapat menurunkan kandungan serat kasar, karena urea dapat menyebabkan perubahan struktur dinding sel. Perubahan ini disebabkan adanyanya proses hidrolisis dari urea yang mampu memecah ikatan lignoselulosa dan lignohemiselulosa, serta melarutkan silika dan lignin yang terdapat dalam dinding sel (Eko, et al. 2013).

Tabel 3. Uji Duncan Pengaruh Perlakuan Urea terhadap Kandungan Protein Kasar

\begin{tabular}{clc}
\hline Perlakuan & $\begin{array}{c}\text { Rataan } \\
\text { Serat } \\
\text { Kasar }(\%)\end{array}$ & $\begin{array}{c}\text { Signifikasi } \\
(\mathbf{0 , 0 5})\end{array}$ \\
\hline N3 & 7,46 & $\mathrm{a}$ \\
N2 & 9,37 & $\mathrm{~b}$ \\
N1 & 11,10 & $\mathrm{c}$ \\
\hline Keterangan : & Superskrip huruf yang berbeda \\
& pada kolom signifikasi \\
& menunjukkan berbeda nyata \\
& (P<0,05)
\end{tabular}

Hal yang sama terjadi pada pemberian sulfur terhadap serat kasar yang menunjukan bahwa pemberian sulfur memberikan pengaruh terhadap penurunan kandungan serat kasar $(\mathrm{P}<0,05)$. Nilai rata-rata kandungan serat kasar terendah diperoleh dari pemberian dosis sulfur tinggi yaitu $0,04 \%$ (S3) dengan rata-rata serat kasar $8,73 \%$. Semakin tinggi penambahan sulfur, maka dapat menurunkan kandungan serat kasar pada limbah padat bioetanol.

Tabel 4. Uji Duncan Pengaruh Perlakuan Sulfur terhadap Kandungan Serat Kasar

\begin{tabular}{ccc}
\hline Perlakuan & $\begin{array}{c}\text { Rataan } \\
\text { Serat } \\
\text { Kasar }(\%)\end{array}$ & $\begin{array}{c}\text { Signifikasi } \\
(\mathbf{0 , 0 5})\end{array}$ \\
\hline S3 & 8,73 & $\mathrm{a}$ \\
S2 & 9,38 & $\mathrm{~b}$ \\
S1 & 9,81 & $\mathrm{~b}$ \\
\hline
\end{tabular}


Keterangan : Superskrip huruf yang berbeda pada kolom signifikasi menunjukkan berbeda nyata $(\mathrm{P}<0,05)$

Penurunan kadar serat kasar disebabkan oleh mikroorganisme yang terkandung dalam EM-4, yaitu Saccharomyces cerevivisiae, Lactobacillus casei dan Rhodopseudomonas palustris. Mikroba tersebut dapat menghasilkan enzim yang memiliki kemampuan untuk mendegradasi serat kasar. Selama proses fermentasi terjadi pemecahan serat (selulosa atau hemiselulosa) menjadi karbohidratkarbohidrat yang lebih sederhana. Mikroorganisme dalam EM-4 menghasilkan enzim yang dapat mencerna serat kasar seperti selulase dan mannase. Selain itu kemampuan bakteri Lactobacillus dalam mencerna serat kasar selama pertumbuhannya, sehingga lebih efektif dalam menurunkan kadar serat kasar dibandingkan ragi dan jamur (Santoso dan Aryani, 2007). Aktivitas bakteri Lactobacillus dalam memfermentasi bahan pakan ternak dari ampas tahu mampu menurunkan kandungan serat kasar. Penurunan kadar serat kasar oleh Lactobacillus casei digunakan untuk metabolisme sel (Tifani, et al. 2015).

\section{SIMPULAN}

Dari hasil uraian di atas dapat disimpulkan bahwa penggunaan urea dan sulfur memberikan interaksi pada kandungan protein kasar akan tetapi tidak pada serat kasar pada limbah padat bioethanol yang difermentasi EM-4 dan secara mandiri faktor pemberian urea dan sulfur menunjukkan pengaruh yang nyata $(\mathrm{P}<0,05)$. Dosis urea $3 \%$ dan sulfur $0,04 \%$ memberikan hasil yang optimal yaitu meningkatkan kandungan protein dari 2,25\% menjadi 14,44 \% dan menurunkan kandungan serat kasar dari $16,57 \%$ menjadi $6,97 \%$.

\section{DAFTAR PUSTAKA}

Akbar, R.T.M, Yani Suryani, Iman Hernaman. 2015. Peningkatan Nutrisi Limbah Produksi Bioetanol Dari Singkong Melalui Fermentasi Oleh Konsorsium Saccharomyces cereviseae dan Trichoderma viride Jurnal Sainteks Volume VIII No. 2 1-15

Akib, M. Akhsan, Henny Setiawaty, Haniarti, dan Sulfiah. 2014. Improving the quality of "leri" rice washing waste by different period of fermentation and yeast concentration as an alternative liquid organic fertilizer. International Journal of Agriculture System (IJAS) Volume 2. 153-162

Association of Official Analytical Chemists (AOAC). 1980. Official Methods of Analysis Association of Official Analytical Chemists. $13^{\text {th }}$ Edition.

Dhalika, T, Mansyur, dan A. Budiman. 2012. Evaluasi karbohidrat dan lemak batang tanaman pisang (Musa paradisiaca. Val) hasil fermentasi anaerob dengan suplementasi nitrogen dan sulfur sebagai bahan pakan ternak. Pastura 1(2) : 97-101.

Eko, P, Dede., M. Junus dan Moch Nasich. 2013. The effect of urea additive to the content of crude protein and crude fiber of the biogas sludge solids. Fakultas Peternakan. Universitas Brawijaya. Malang.

Islamiyati, R. 2014. Nilai nutrisi campuran feses sapi dan beberapa level ampas kelapa yang difermentasi dengan EM-4. Buletin Nutrisi dan Makanan Ternak. Vol 10 (1) 41-46.

Irawan, S. dan Utama. 2012. Komponen proksimat pada jerami padi dan jerami jagung yang difermentasi dengan berbagai aras isi rumen kerbau. Animal Agiculture Journal Fakultas Peternakan dan Pertanian Universitas Diponegoro, Vol.1 (2), 17-30.

Kukuh R, Hafied . 2010. Pengaruh Suplementasi Probiotik Cair EM4 terhadap Performan Domba Lokal Jantan. Surakarta : Fakultas Pertanian Universitas Sebelas Maret.

Manfaati, R. 2010. Kinetika dan Variabel Optimum Fermentasi Asam Laktat dengan Media Campuran Tepung Tapioka dan Limbah Cair Tahu oleh Rhizopus oryzae. Naskah Tesis S-2. Program Magister Teknik Kimia. Universitas Diponegoro, Semarang.

Permata, A.T. 2012. Pengaruh amoniasi dengan urea pada ampas tebu terhadap kandungan bahan kering, serat kasar dan protein kasar untuk penyediaan pakan ternak. Artikel Ilmiah. Fakultas Kedokteran Hewan. Universitas Airlangga. Surabaya.

Pratomo, Heru dan E. Rohaeti. 2011. Bioplastik nata de cassava sebagai bahan edible film ramah lingkungan. Jurnal Penelitian Saintek 16 (2) 172178. 
Santoso, U. dan Aryani, I. 2007. Perubahan komposisi kimia daun ubi kayu yang difermentasi oleh EM4. Jurnal Sains. Peternakan Indonesia. 2 (2) :53- 56.

Steel, R.G.D., dan Torrie, J.H. 1993. Prinsip dan Prosedur Statistika. PT. Gramedia Pustaka Utama.

Suprayogi, W. P. S. 2010. Inkorporasi sulfur dalam protein onggok melalui teknologi fermentasi menggunakan Sacharomyces cerevisiae. Carakan Tani XXV No 1.3437

Suprihatin. 2010. Teknologi Fermentasi. UNESA Press. Surabaya.

Suryani, Yani, Iman H., Ayu, S., Gilang D. P., dan Poniah A. 2013. The effect of nitrogen and sulfur addition on bioethanol solid waste fermented by the consortium of trichoderma viride and saccharomyces cerevisiae towards dry materials, organic materials, crude protein and non nitrogen protein. Asian Journal of Agriculture and Rural Development, 3(9) 2013: 622-631

Tifani, Muhammad Anjang, Sri Kumalaningsih, dan Arie Febrianto Mulayadi. 2015. Produksi bahan pakan ternak dari ampas tahu dengan fermentasi menggunakan EM-4 (kajian $\mathrm{pH}$ awal dan lama waktu fermentasi). Jurnal Pangan dan Agroindustri Vol. 3 No. 3 889-898. 